\title{
Descriptions of strigea cercariae from the Gauteng and North West Provinces, South Africa
}

\begin{abstract}
Authors:
Esmey B.E. Moema

Pieter H. King ${ }^{1}$

Chantelle Baker ${ }^{2}$

Affiliations:

${ }^{1}$ Department of Biology,

University of Limpopo

Medunsa campus,

South Africa

2Electron Microscope Unit, University of Limpopo, Medunsa campus,

South Africa

\section{Correspondence to:}

Esmey Moema

Email:

Esmey.Moema@ul.ac.za

Postal address:

PO Box 139, Medunsa 0204 South Africa

Dates:

Received: 06 Feb. 2012

Accepted: 18 Apr. 2012

Published: 14 Sept. 2012

How to cite this article: Moema, E.B.E., King, P.H. \& Baker, C., 2012, 'Descriptions of strigea cercariae from the Gauteng and North West Provinces, South Africa', Onderstepoort Journal of Veterinary Research 79(1), Art. \#410, 8 pages. http:// dx.doi.org/10.4102/ojvr. v79i1.410
\end{abstract}

(C) 2012. The Authors. Licensee: AOSIS OpenJournals. This work is licensed under the Creative Commons Attribution License.
Freshwater snails are known to serve as first intermediate hosts for various parasitic diseases such as schistosomosis, amphistomosis and fasciolosis. Two freshwater snail species, Lymnaea natalensis, Krauss 1848 and Bulinus tropicus, Krauss 1848 were sampled from five localities in Gauteng and one locality in the North West Province from 2007 to 2010. These snails were collected in order to study their cercarial sheddings. They were found to be infected with three different types of strigea cercariae, of which the morphology was studied using standard light and scanning electron microscopy techniques.

\section{Introduction}

Strigea cercariae are characterised by a tail with long furcae (longifurcate), a pharynx (pharyngeal) and the presence of both oral and ventral suckers (distome). These cercariae are known to encyst in snails, tadpoles, reptiles and fish. Adults, as intestinal parasites of birds and mammals, are usually classified in either the family Strigeidae or Diplostomatidae (Frandsen \& Christensen 1984).

The most comprehensive work on cercarial types, distribution and morphology in southern Africa was published by Porter (1938). Fain (1953) studied the cercariae from snails in Lake Albert (on the border of the Democratic Republic of the Congo and Uganda) and Vercammen-Grandjean (1960) from Lake Kivu (on the border of the Democratic Republic of the Congo and Rwanda). Later, Combes (1980) presented the 'World atlas of cercariae', whereafter King and Van As (1997, 2001) described the cercariae shed by Bulinus tropicus, Krauss 1848 in the Free State. Jansen van Rensburg (2001) described the cercariae from snail species in the Okavango Delta, Botswana and Nadasan and Appleton (2003) investigated the cercariae in the vicinity of Durban, KwaZulu-Natal.

Surveys on cercarial sheddings in the Tshwane area, Gauteng Province and one locality in the North West Province revealed two freshwater snail species to shed three different types of strigea cercariae. Lifecycle studies on these parasites frequently failed, mainly because of their extremely high host specificity with regard to their first, second and definitive hosts. The main aim of this project was to gather morphological information on these cercarial types, which, in the future, may assist in establishing possible linkages with strigea metacercarial stages in local fish populations from these areas.

\section{Materials and methods}

The freshwater snails, Lymnaea natalensis, Krauss 1848 and B. tropicus were collected over a period of four years (2007-2010) from four localities, namely, Supersand Dam (25 35'02.42" S $-28^{\circ} 10^{\prime} 38.98^{\prime \prime} \mathrm{E}$, altitude $1198 \mathrm{~m}$ a.s.l.) situated $\pm 2 \mathrm{~km}$ north of the Bon Accord Dam in the Onderstepoort area, Gauteng; the Boekenhoutskloof farm Dam $\left(25^{\circ} 32^{\prime} 45.18^{\prime \prime} \mathrm{S}-28^{\circ} 26^{\prime} 12.47^{\prime \prime}\right.$ E, altitude $1214 \mathrm{~m}$ a.s.l.), approximately $15 \mathrm{~km}$ north of the Roodeplaat Dam Nature Reserve,

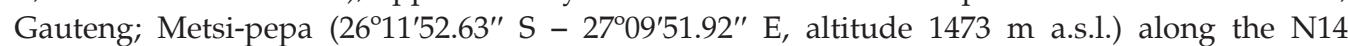
Krugersdorp-Ventersdorp main road and $\pm 35 \mathrm{~km}$ from Ventersdorp, North West Province;

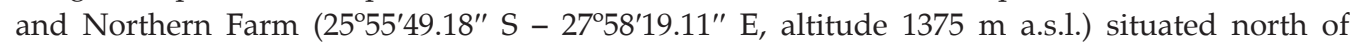
Johannesburg, Gauteng, bordering the Diepsloot informal settlement. The snails were collected using metal scoops, as described by Van Eeden (1960), or collected manually from the ventral surface of water lily leaves. In the laboratory they were kept in plastic containers and fed fish flakes. They were exposed to indirect daylight to stimulate the natural shedding of cercariae.

The cercariae were stained with Nile blue sulphate or neutral red vital stains and studied alive using a Nikon compound microscope (Nikon, Tokyo, Japan). One or two stained cercariae were placed in a drop of water on a microscope slide, covered with a glass cover slip and moved once or twice over a Bunsen burner to slow down cercarial movement. Drawings were made by means of a drawing tube. In all cases, 20 specimens were measured, with all measurements given in 
micrometres $(\mu \mathrm{m})$ and with minimum and maximum values indicated along with the mean value and standard deviation in parenthesis. Owing to the low infections in the snails, no other intra-molluscan stages were studied.

For scanning electron microscopy (SEM), specimens were fixed overnight in 2.5\% glutaraldehyde, washed in Millonig's phosphate buffer $(\mathrm{pH}=7.2)$ and dehydrated through a graded ethanol series for $30 \mathrm{~s}-60 \mathrm{~s}$ in each concentration. Thereafter, they were critically point dried (Polaron, Watford, UK), mounted on aluminium stubs, sputter coated with gold (Emscope; Quorum Technologies, Ashford, UK) and examined using a Leica Stereoscan 420 SEM (Leica Electron Optics, UK) at the Electron Microscope Unit of the University of Limpopo (Medunsa campus).

\section{Ethical considerations}

This research project met the requirements of the Research Ethics Committee (BP 05/2005) and the Animal Ethics Committee (AEC 02/05) of the University of Limpopo. Snails were kept under controlled laboratory conditions with sufficient light, air and food according to acceptable standards. They were individually placed in containers and cercariae collected after natural shedding.

\section{Results}

The freshwater snails, L. natalensis and B. tropicus were found to host three types of strigea cercariae. Table 1 accounts for the total collection of these two snail species from the four localities over a period of four years from 2007 to 2010. The prevalence of each infection is also indicated.

\section{Strigea cercaria A}

Snail host: L. natalensis.

Locality: Supersand Dam, Gauteng Province.

The cercaria (Figure 1a; Figures $2 a$ and $2 b$ ) consists of an elongated and cylindrical body, measuring $164 \mu \mathrm{m}-185 \mu \mathrm{m}$ $(180 \mu \mathrm{m} \pm 7 \mu \mathrm{m})$ long $\times 49 \mu \mathrm{m}-60 \mu \mathrm{m}(52 \mu \mathrm{m} \pm 4 \mu \mathrm{m})$ wide and a tail stem ending in two caudal rami (Figure $1 \mathrm{~b}$ ). The tail stem is shorter than the length of the body, measuring $198 \mu \mathrm{m}-206 \mu \mathrm{m}(201 \mu \mathrm{m} \pm 3 \mu \mathrm{m}) \times 24 \mu \mathrm{m}-29 \mu \mathrm{m}(26 \mu \mathrm{m}$ $\pm 2 \mu \mathrm{m})$, with the caudal rami shorter than the tail stem, at $169 \mu \mathrm{m}-174 \mu \mathrm{m}(172 \mu \mathrm{m} \pm 2 \mu \mathrm{m}) \times 16 \mu \mathrm{m}-18 \mu \mathrm{m}$ $(17 \mu \mathrm{m} \pm 1 \mu \mathrm{m})$.

A pear-shaped oral sucker, $52 \mu \mathrm{m}-69 \mu \mathrm{m}(59 \mu \mathrm{m} \pm 4 \mu \mathrm{m}) \times$ $18 \mu \mathrm{m}-31 \mu \mathrm{m}(27 \mu \mathrm{m} \pm 4 \mu \mathrm{m})$ is situated at the anterior end of the body. Sensory receptors with short cilia were observed alongside the oral sucker (Figure 2c). A pre-pharynx, $4 \mu \mathrm{m}$ $-7 \mu \mathrm{m}(6.5 \mu \mathrm{m} \pm 1.0 \mu \mathrm{m}) \times 3 \mu \mathrm{m}-4 \mu \mathrm{m}(3.5 \mu \mathrm{m} \pm 1.0 \mu \mathrm{m})$ connects the oral sucker to the pharynx, $12 \mu \mathrm{m}-19 \mu \mathrm{m}$ $(14 \mu \mathrm{m} \pm 2 \mu \mathrm{m}) \times 10 \mu \mathrm{m}-21 \mu \mathrm{m}(13 \mu \mathrm{m} \pm 3 \mu \mathrm{m})$, followed by an oesophagus, $7 \mu \mathrm{m}-12 \mu \mathrm{m}(8 \mu \mathrm{m} \pm 1 \mu \mathrm{m}) \times 4 \mu \mathrm{m}-6 \mu \mathrm{m}$ $(5 \mu \mathrm{m} \pm 1 \mu \mathrm{m})$ that extends to just anterior of the acetabulum. The oesophagus divides into two intestinal caeca, $82 \mu \mathrm{m}$ $-85 \mu \mathrm{m}(83 \mu \mathrm{m} \pm 1 \mu \mathrm{m}) \times 5 \mu \mathrm{m}-6 \mu \mathrm{m}(5.5 \mu \mathrm{m} \pm 1.0 \mu \mathrm{m})$ that extend posteriorly and terminates close to the posterior end of the body.

The acetabulum (Figure 2d), $35 \mu \mathrm{m}-39 \mu \mathrm{m}(36 \mu \mathrm{m} \pm 1 \mu \mathrm{m}) \times$ $33 \mu \mathrm{m}-37 \mu \mathrm{m}(35 \mu \mathrm{m} \pm 2 \mu \mathrm{m})$ is aspinose and located $28 \mu \mathrm{m}-$ $38 \mu \mathrm{m}(33 \mu \mathrm{m} \pm 4 \mu \mathrm{m})$ from the oral sucker. It is notably smaller than the oral sucker. Four penetration glands posterior to the acetabulum (Figure 1a; Figure $2 \mathrm{~b}$ ) are arranged as follows: two penetration glands, $7 \mu \mathrm{m}-15 \mu \mathrm{m}(10 \mu \mathrm{m} \pm 2 \mu \mathrm{m}) \times$ $9 \mu \mathrm{m}-16 \mu \mathrm{m}(13 \mu \mathrm{m} \pm 2 \mu \mathrm{m})$ flanking each other, followed by two large unpaired penetration glands lying tandem and posterior to the first pair. The first unpaired penetration glands measure $6 \mu \mathrm{m}-10 \mu \mathrm{m}(8 \mu \mathrm{m} \pm 2 \mu \mathrm{m}) \times 16 \mu \mathrm{m}-24 \mu \mathrm{m}$ $(19 \mu \mathrm{m} \pm 2 \mu \mathrm{m})$ and the second pair, $6 \mu \mathrm{m}-10 \mu \mathrm{m}(8 \mu \mathrm{m} \pm$ $1 \mu \mathrm{m}) \times 15 \mu \mathrm{m}-27 \mu \mathrm{m}(19 \mu \mathrm{m} \pm 3 \mu \mathrm{m})$.

A small bipartite excretory bladder, $7 \mu \mathrm{m}-10 \mu \mathrm{m}(8 \mu \mathrm{m}$ $\pm 1 \mu \mathrm{m}) \times 7 \mu \mathrm{m}-11 \mu \mathrm{m}(9 \mu \mathrm{m} \pm 3 \mu \mathrm{m})$ is situated at the posterior end of the body (Figure 1a). Two main collecting tubes arise from the bladder, extend anteriorly and divide into anterior and posterior collecting tubules anterior to the acetabulum. Fourteen pairs of flame cells were found in the body, of which six pairs are located in the anterior half and the remaining eight pairs are located in the posterior half of the body. The flame cell formula is: $2([2+2+2]+[1+2+2$ $+1+2])=28$. The excretory pores open sub-terminally on either side of the caudal rami (Figure 1b).

Posteriorly directed minute spines that are denser in the anterior part of the organism cover the body tegument (Figure 2c), whereas fewer and more widely separated spines cover the tail stem (Figure 2e), with sparse sensory receptors with long cilia on its surface (Figure 2f). Six hair-like structures (Figure 1b), three anteriorly and three posteriorly, were observed on each side of the tail stem. A series of caudal bodies were also observed in the tail stem (Figure 1b). The caudal rami are covered with spines that are visually fewer when compared to the spines found on the tail stem.

\section{Strigea cercaria B}

Snail host: B. tropicus.

Locality: Northern farm Dam, Gauteng Province.

Strigea cercaria B (Figures 1c and 1d; Figures 3a and 3b) comprises a cylindrical body, $88 \mu \mathrm{m}-155 \mu \mathrm{m}$ $(109 \mu \mathrm{m} \pm 21 \mu \mathrm{m}) \times 45 \mu \mathrm{m}-60 \mu \mathrm{m}(50 \mu \mathrm{m} \pm 4 \mu \mathrm{m})$ and $\mathrm{a}$ fork tail. The tail stem, $75 \mu \mathrm{m}-127 \mu \mathrm{m}(105 \mu \mathrm{m} \pm 16 \mu \mathrm{m}) \times$ $28 \mu \mathrm{m}-36 \mu \mathrm{m}(33 \mu \mathrm{m} \pm 3 \mu \mathrm{m})$ is shorter than the body length, with the caudal rami measuring $123 \mu \mathrm{m}-161 \mu \mathrm{m}(149 \mu \mathrm{m}$ $\pm 11 \mu \mathrm{m}) \times 10 \mu \mathrm{m}-21 \mu \mathrm{m}(16 \mu \mathrm{m} \pm 3 \mu \mathrm{m})$. The oral sucker (Figure 3c), $16 \mu \mathrm{m}-40 \mu \mathrm{m}(30 \mu \mathrm{m} \pm 7 \mu \mathrm{m}) \times 25 \mu \mathrm{m}-33 \mu \mathrm{m}$ (30 $\mu \mathrm{m} \pm 3 \mu \mathrm{m})$ is covered by fairly large and sharp backwardly pointing spines (Figures $3 \mathrm{c}$ and $3 \mathrm{~d}$ ). The oral sucker opens directly into a pharynx, $7 \mu \mathrm{m}-10 \mu \mathrm{m}(9 \mu \mathrm{m} \pm$ $1 \mu \mathrm{m}) \times 7 \mu \mathrm{m}-12 \mu \mathrm{m}(10 \mu \mathrm{m} \pm 2 \mu \mathrm{m})$, followed by a short oesophagus, $6 \mu \mathrm{m}-30 \mu \mathrm{m}(13 \mu \mathrm{m} \pm 7 \mu \mathrm{m}) \times 3 \mu \mathrm{m}-6 \mu \mathrm{m}$ $(4 \mu \mathrm{m} \pm 1 \mu \mathrm{m})$ (Figure 1d).

The oesophagus bifurcates into two intestinal caeca, $31 \mu \mathrm{m}-$ $49 \mu \mathrm{m}(42 \mu \mathrm{m} \pm 5 \mu \mathrm{m}) \times 4 \mu \mathrm{m}-9 \mu \mathrm{m}(6 \mu \mathrm{m} \pm 1 \mu \mathrm{m})$, encircling 
TABLE 1: Prevalence of infections of two freshwater snail species collected from four different localities across the Gauteng and North West Provinces, South Africa.

\begin{tabular}{|c|c|c|c|c|c|c|c|c|}
\hline \multirow{4}{*}{$\begin{array}{l}\text { Year of } \\
\text { collection }\end{array}$} & \multicolumn{8}{|c|}{ Snail species collected } \\
\hline & \multicolumn{4}{|c|}{ Lymnaea natalensis } & \multirow{2}{*}{\multicolumn{4}{|c|}{$\begin{array}{c}\text { Bulinus tropicus } \\
\text { Strigea cercaria B }\end{array}$}} \\
\hline & \multicolumn{2}{|c|}{ Strigea cercaria $\mathrm{A}$} & \multicolumn{2}{|c|}{ Strigea cercaria C } & & & & \\
\hline & $\begin{array}{l}\text { Number of snails } \\
\text { collected from } \\
\text { Supersand dam }\end{array}$ & $\begin{array}{c}\text { Prevalence } \\
(\%)\end{array}$ & $\begin{array}{l}\text { Number of snails } \\
\text { collected from } \\
\text { Metsi-Pepa }\end{array}$ & $\begin{array}{c}\text { Prevalence } \\
(\%)\end{array}$ & $\begin{array}{l}\text { Number of snails } \\
\text { collected from } \\
\text { Northern farm }\end{array}$ & $\begin{array}{c}\text { Prevalence } \\
(\%)\end{array}$ & $\begin{array}{c}\text { Number of snails } \\
\text { collected from Boeken } \\
\text { houtskloof }\end{array}$ & $\begin{array}{c}\text { Prevalence } \\
(\%)\end{array}$ \\
\hline 2007 & 39 & 3.0 & 18 & 7.7 & 13 & 2 & 57 & 13.5 \\
\hline 2008 & 38 & 2.7 & 21 & 7.3 & 17 & 4 & 19 & 10.0 \\
\hline 2009 & 5 & 2.0 & 57 & 7.9 & 27 & 7 & 8 & 7.0 \\
\hline 2010 & 123 & 4.0 & 107 & 8.0 & 0 & 0 & 132 & 14.0 \\
\hline
\end{tabular}

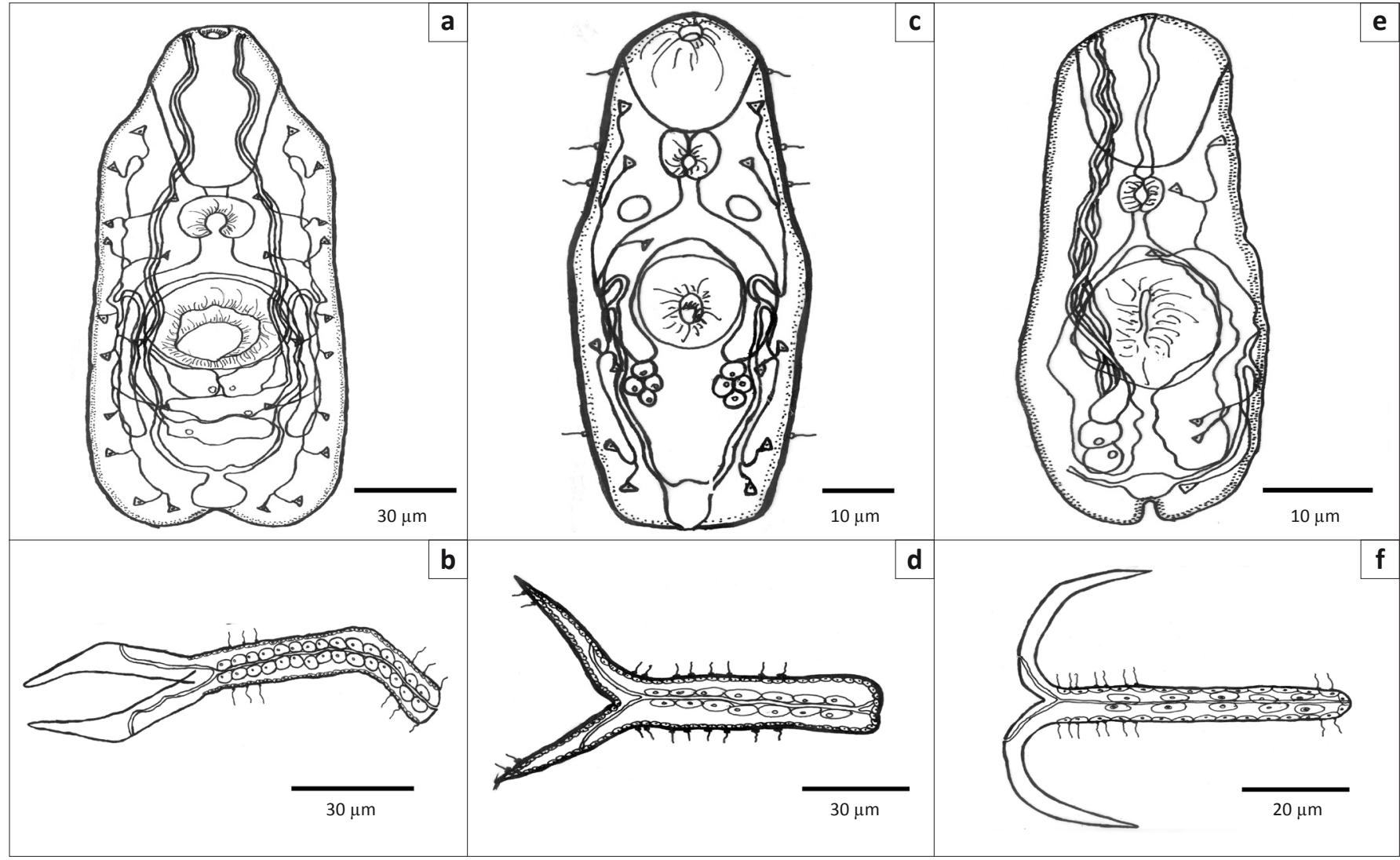

FIGURE 1: Light microscope projection drawings of three types of strigea cercariae shed by Lymnaea natalensis and Bulinus tropicus, (a) head and (b) forked-tail of strigea cercaria A, (c) head and (d) forked tail of strigea cercaria B and (e) head and ( $f$ ) forked tail of strigea cercaria C.

the acetabulum and terminate posteriorly to the acetabulum. The acetabulum (Figure 3e), $18 \mu \mathrm{m}-30 \mu \mathrm{m}(25 \mu \mathrm{m} \pm 4 \mu \mathrm{m}) \times$ $18 \mu \mathrm{m}-25 \mu \mathrm{m}(22 \mu \mathrm{m} \pm 2 \mu \mathrm{m})$ is smaller than the oral sucker and situated $43 \mu \mathrm{m}-90 \mu \mathrm{m}(58 \mu \mathrm{m} \pm 15 \mu \mathrm{m})$ mid-ventrally from the anterior end of the body. Two non-pigmented eyespots are situated $46 \mu \mathrm{m}-48 \mu \mathrm{m}(47 \mu \mathrm{m} \pm 1 \mu \mathrm{m})$ from the anterior end of the body and measure $7 \mu \mathrm{m}-10 \mu \mathrm{m}(9 \mu \mathrm{m} \pm$ $1 \mu \mathrm{m}) \times 4 \mu \mathrm{m}-9 \mu \mathrm{m}(6 \mu \mathrm{m} \pm 2 \mu \mathrm{m})($ Figure $1 \mathrm{~d})$.

Four small penetration glands (Figure 1d), $4 \mu \mathrm{m}-7 \mu \mathrm{m}(6 \mu \mathrm{m}$ $\pm 1 \mu \mathrm{m}$ ) in diameter, are situated at the terminal end of each intestinal caecum. A small bipartite excretory bladder, $3 \mu \mathrm{m}$ $-9 \mu \mathrm{m}(7 \mu \mathrm{m} \pm 2 \mu \mathrm{m}) \times 7 \mu \mathrm{m}-15 \mu \mathrm{m}(10 \mu \mathrm{m} \pm 3 \mu \mathrm{m})$, is located at the posterior end of the body. Two main collecting tubes arise from the bladder, extend anteriorly and divide into anterior and posterior collecting tubules anterior to the acetabulum giving rise to capillaries that terminate in flame cells (Figure 1d). The flame cell formula is: $2([2+1]+[2+2])$
$=14$. The excretory pore opens sub-terminally on the lateral side of each caudal ramus (Figure 1c).

The body surface is covered with many posteriorly facing spines that are concentrated more at the anterior end of the body. These spines are large and concentrated around the oral sucker (Figure 3c), and become smaller towards the posterior. A row of large spines surrounds the acetabulum wall (Figure 3e). Four hair-like structures (Figure 1d) were observed: three on the anterior half and one posterior on both sides of the body. The tail stem (Figure 3f) is covered with only a few short spines that are randomly positioned. The caudal rami are covered with fewer posteriorly directed spines.

Both the tail stem and the caudal rami have hair-like structures, eight were found on both sides of the tail stem and two on the postero-lateral side of each caudal ramus (Figure 1c). 

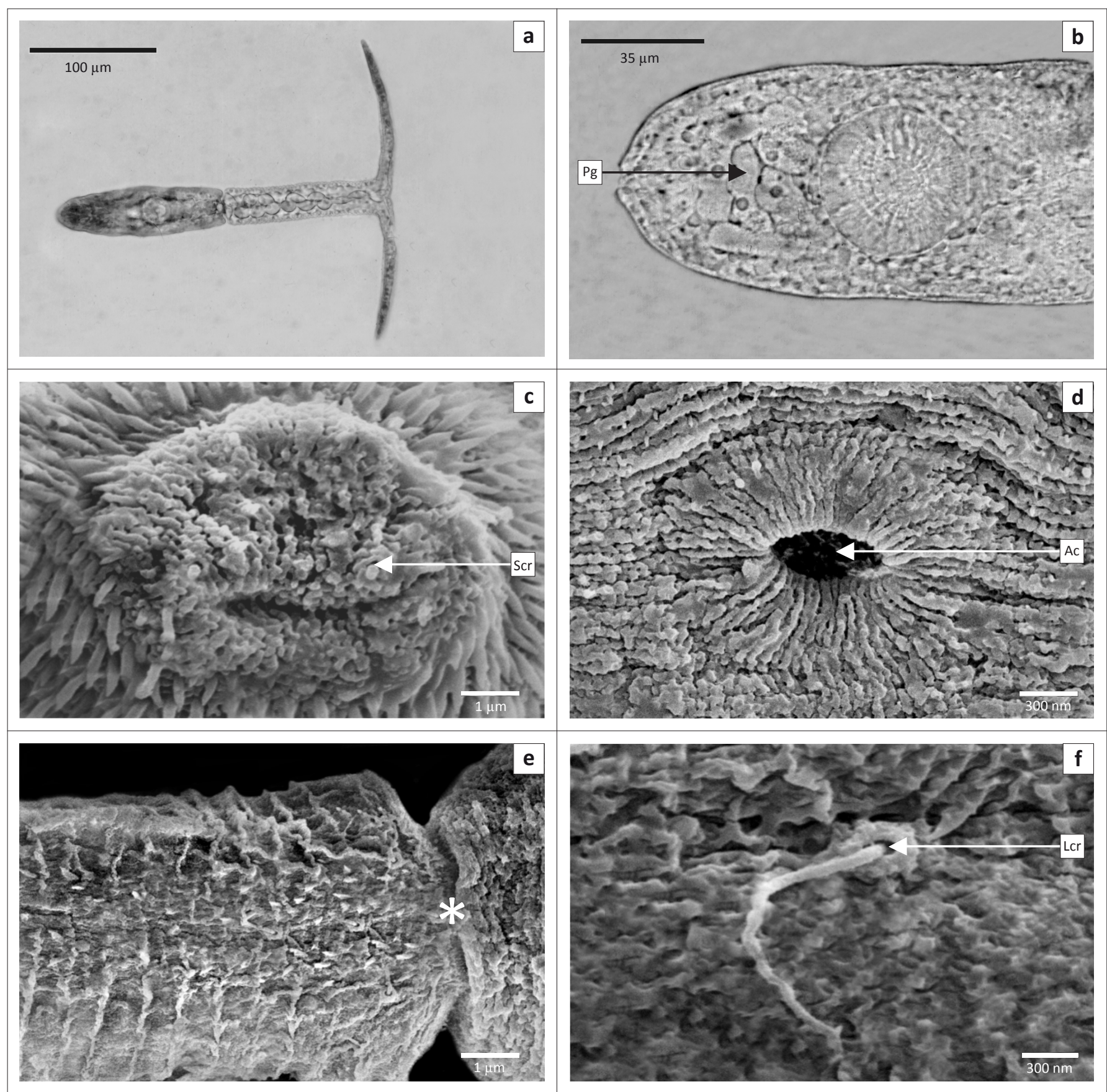

FIGURE 2: Strigea cercaria A, depicted using light micrographs of (a) whole mount and (b) head of cercariae with penetration glands (Pg) posterior to acetabulum, as well as scanning electron micrographs of, (c) oral sucker (Os), (d) acetabulum (Ac), (e) joint between body and tail (*) and (f) sensory receptors with long cilia (Lcr) on the tail stem.

\section{Strigea cercaria C}

Snail host: L. natalensis.

Locality: Metsi-pepa, North West Province.

Strigea cercaria $C$ is elongated with a large oval-shaped body, $151 \mu \mathrm{m}-184 \mu \mathrm{m}(171 \mu \mathrm{m} \pm 10 \mu \mathrm{m}) \times 45 \mu \mathrm{m}-52 \mu \mathrm{m}$ $(50 \mu \mathrm{m} \pm 3 \mu \mathrm{m})$, and a fork tail that is almost twice as long as the body (Figures 1e and 1f; Figures $4 \mathrm{a}$ and $4 \mathrm{~b}$ ). The tail stem measures $413 \mu \mathrm{m}-508 \mu \mathrm{m}(479 \mu \mathrm{m} \pm 31 \mu \mathrm{m}) \times 66 \mu \mathrm{m}-$ $90 \mu \mathrm{m}(72 \mu \mathrm{m} \pm 9 \mu \mathrm{m})$. The caudal rami, at $407 \mu \mathrm{m}-497 \mu \mathrm{m}$ $(477 \mu \mathrm{m} \pm 29 \mu \mathrm{m}) \times 30 \mu \mathrm{m}-60 \mu \mathrm{m}(38 \mu \mathrm{m} \pm 8 \mu \mathrm{m})$, are as long as the tail stem and taper posteriorly into sharp-ending points (Figure 1f).
The body (Figure 1e; Figure $4 \mathrm{~b}$ ) displays a pear-shaped oral sucker, $48 \mu \mathrm{m}-64 \mu \mathrm{m}(57 \mu \mathrm{m} \pm 5 \mu \mathrm{m}) \times 22 \mu \mathrm{m}-33 \mu \mathrm{m}$ $(28 \mu \mathrm{m} \pm 4 \mu \mathrm{m})$, that is longer than wide and very protrusible. Sensory receptors with short cilia dominate the area around the mouth opening (Figures $4 \mathrm{~d}$ and $4 \mathrm{e}$ ). Posteriorly directed spines (Figures $4 \mathrm{~d}$ and $4 \mathrm{e}$ ) are concentrated at the anterior end of the body, especially around the oral sucker, but are fewer in number at the posterior end of the body. Sensory receptors with long cilia were observed dorsally on the body surface (Figure 4f).

A small oral opening (Figure 4d) situated in the middle of the oral sucker opens into a pre-pharynx, $9 \mu \mathrm{m}-15 \mu \mathrm{m}$ 

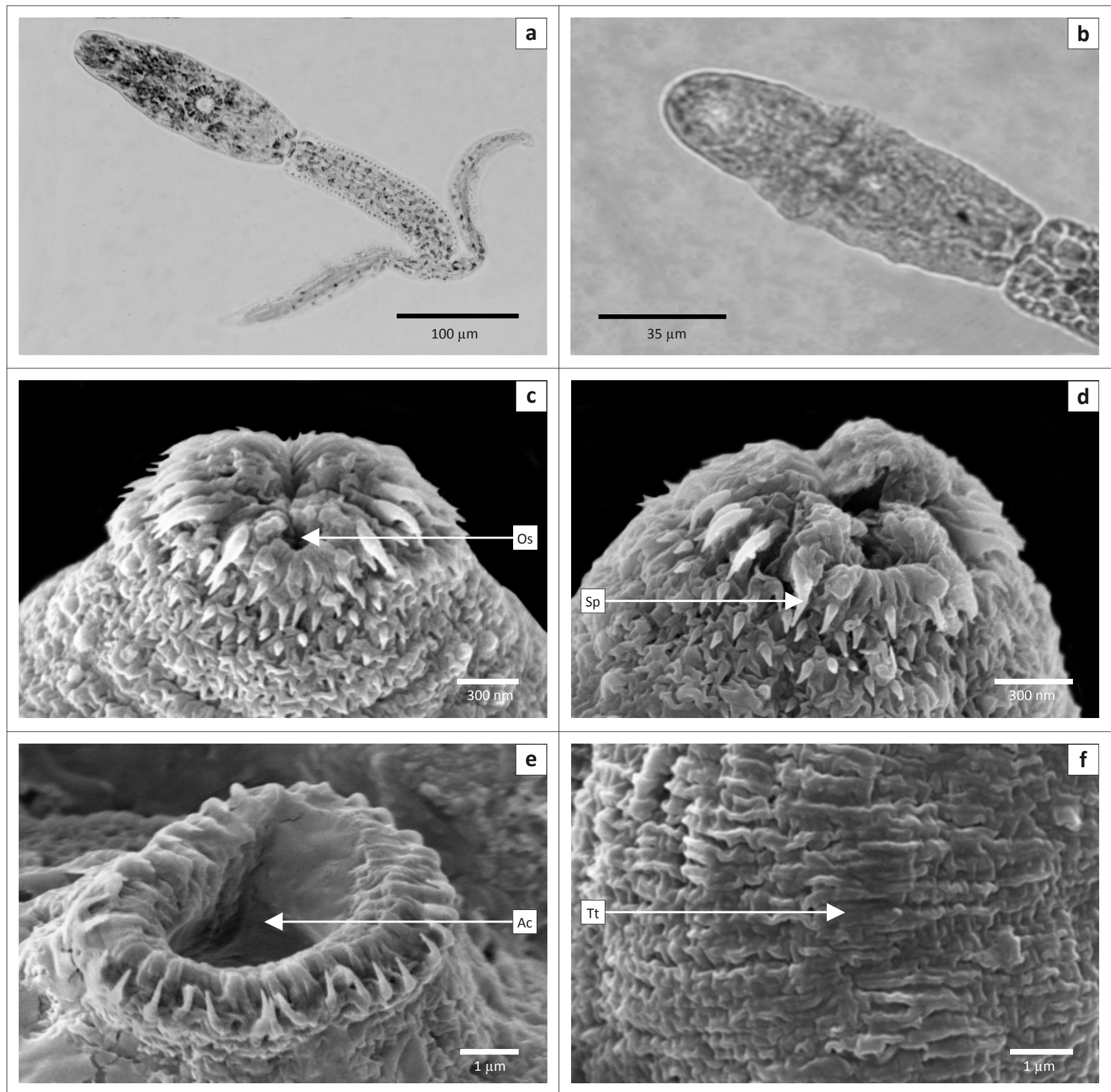

FIGURE 3: Strigea cercaria B, depicted using light micrographs of (a) whole mount and (b) head of cercaria, as well as scanning electron micrographs of, (c) oral sucker (Os), (d) spines (Sp) around the oral sucker, (e) acetabulum (Ac) and (f) tail tegument (Tt).

$(12 \mu \mathrm{m} \pm 2 \mu \mathrm{m}) \times 4 \mu \mathrm{m}-7 \mu \mathrm{m}(6 \mu \mathrm{m} \pm 1 \mu \mathrm{m})$. It continues into a muscular pharynx, $10 \mu \mathrm{m}-15 \mu \mathrm{m}(11 \mu \mathrm{m} \pm 2 \mu \mathrm{m}) \times$ $9 \mu \mathrm{m}-15 \mu \mathrm{m}(11 \mu \mathrm{m} \pm 2 \mu \mathrm{m})$, leading to a short oesophagus, $7 \mu \mathrm{m}-12 \mu \mathrm{m}(9 \mu \mathrm{m} \pm 2 \mu \mathrm{m}) \times 3 \mu \mathrm{m}-6 \mu \mathrm{m}(4 \mu \mathrm{m} \pm 1 \mu \mathrm{m})$. The oesophagus divides at the level of the acetabulum into two very large intestinal caeca, $67 \mu \mathrm{m}-97 \mu \mathrm{m}(80 \mu \mathrm{m} \pm 8 \mu \mathrm{m}) \times$ $10 \mu \mathrm{m}-16 \mu \mathrm{m}(13 \mu \mathrm{m} \pm 2 \mu \mathrm{m})$ that terminate just above the excretory bladder at the posterior end of the body.

An acetabulum, $12 \mu \mathrm{m}-39 \mu \mathrm{m}(33 \mu \mathrm{m} \pm 8 \mu \mathrm{m}) \times 30 \mu \mathrm{m}-$ $39 \mu \mathrm{m}(34 \mu \mathrm{m} \pm 3 \mu \mathrm{m})$, with spines on the luminal wall is situated $37 \mu \mathrm{m}-40 \mu \mathrm{m}(39 \mu \mathrm{m} \pm 1 \mu \mathrm{m})$ posterior to the elongated oral sucker. Three finely granular penetration glands occur in tandem on either side of the body, just posterior to the acetabulum. The first pair measures, $9 \mu \mathrm{m}-$ $15 \mu \mathrm{m}(13 \mu \mathrm{m} \pm 2 \mu \mathrm{m}) \times 10 \mu \mathrm{m}-13 \mu \mathrm{m}(11 \mu \mathrm{m} \pm 1 \mu \mathrm{m})$, the second pair, $7 \mu \mathrm{m}-15 \mu \mathrm{m}(13 \mu \mathrm{m} \pm 2 \mu \mathrm{m}) \times 10 \mu \mathrm{m}-13 \mu \mathrm{m}$ $(11 \mu \mathrm{m} \pm 1 \mu \mathrm{m})$ and the third pair, $10 \mu \mathrm{m}-16 \mu \mathrm{m}(14 \mu \mathrm{m} \pm$ $2 \mu \mathrm{m}) \times 10 \mu \mathrm{m}-13 \mu \mathrm{m}(12 \mu \mathrm{m} \pm 1 \mu \mathrm{m})$.

The excretory system consists of an oval-shaped bladder, $7 \mu \mathrm{m}-10 \mu \mathrm{m}(8 \mu \mathrm{m} \pm 1 \mu \mathrm{m}) \times 6 \mu \mathrm{m}-10 \mu \mathrm{m}(8.0 \mu \mathrm{m} \pm$ $1.9 \mu \mathrm{m})$ from where the main excretory ducts on each side of the bladder run anteriorly towards the middle of the body. These ducts then divide at the level of the acetabulum into anterior and posterior collecting tubules which branch into 
smaller capillaries bearing flame cells. The flame cell formula is as follows: $2(3+3)=12$. Two hair-like structures were observed bilaterally on the anterior end and seven pairs on the posterior half of the tail stem (Figure 1f). Caudal bodies in the tail stem are irregular in size and shape, and vary in number (Figure 1f; Figure 4c).

\section{Trustworthiness}

\section{Reliability}

Repeated measurement $(n=20)$ of morphological characteristics by both line drawings and comparative information from SEM micrographs, corroborate our findings and thus improves reliability.

\section{Validity}

All measurements included are of internationally accepted and well-recognised taxonomic descriptors in this discipline.

\section{Discussion}

All three of the cercariae were identified as strigea cercariae according to the identification keys provided by Frandsen and Christensen (1984), classifying them as longifurcatepharyngeal distome cercariae of the superfamily Strigeoidea.

Porter (1938) described three fork-tailed cercariae shed by $L$. natalensis, namely Cercaria scheerpoortia and Cercaria magaliesia both from Hartebeestpoort Dam (North West
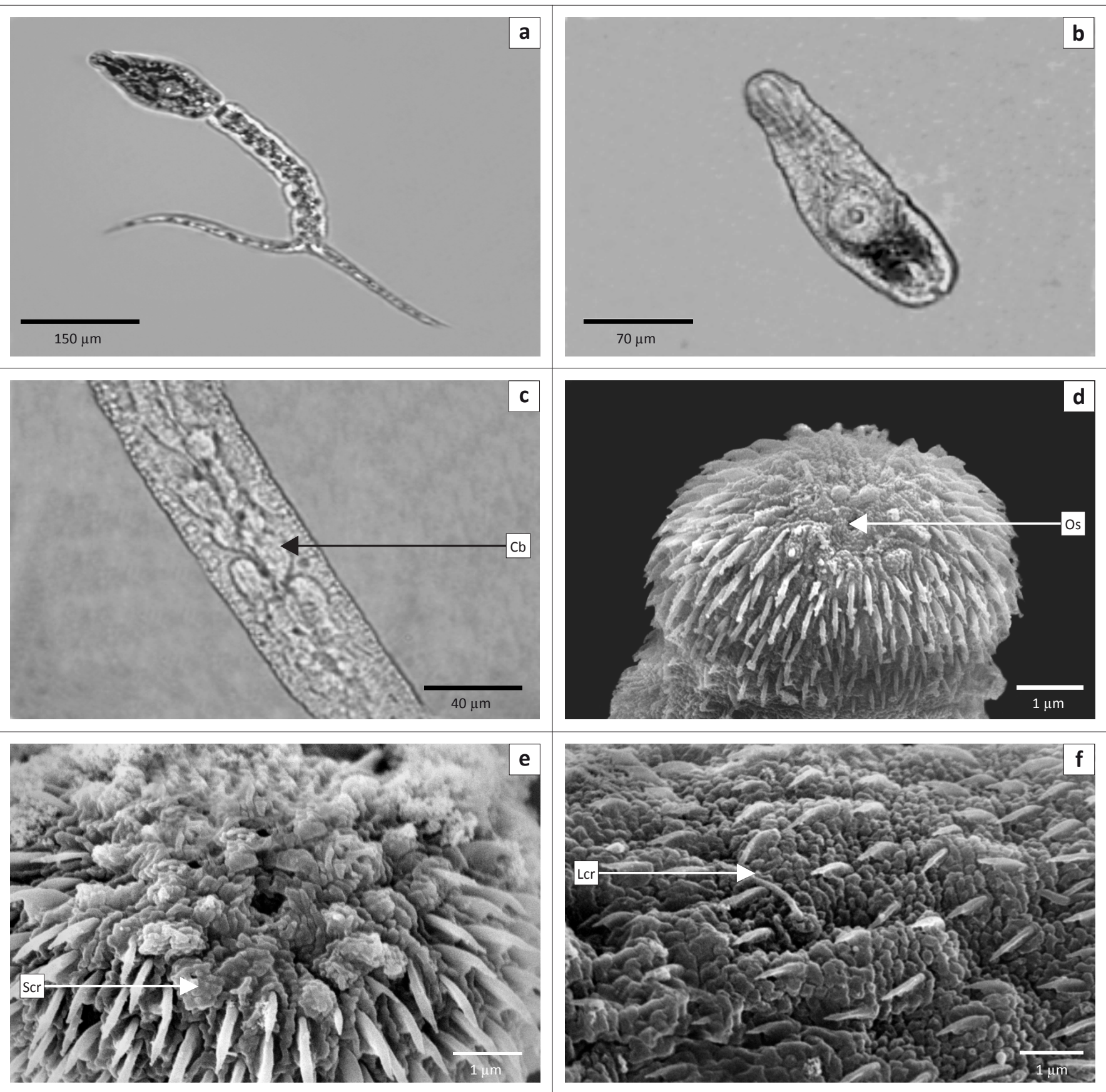

FIGURE 4: Strigea cercaria C, depicted using light micrographs of (a) whole mount, (b) head of cercaria and (c) caudal bodies (Cb) in the tail stem, as well as scanning electron micrographs of, (d) oral sucker (Os), (e) sensory receptors with short cilia (Scr) surrounding the oral sucker and (f) sensory receptors with long cilia (Lcr) anteroventrally on the body. 
Province) and Cercaria maritzburgensis from Pietermaritzburg (KwaZulu-Natal Province). Fain (1953) described nine strigea cercariae, which included one secreted by L. natalensis. Furthermore, Vercammen-Grandjean (1960) described six strigea cercariae which included five secreted by Biomphalaria species and one by $L$. natalensis from Lake Kivu. More recently, King and Van As (2001) described a fork-tailed cercaria secreted by B. tropicus from the Free State Province, whilst Jansen van Rensburg (2001) described a forktailed cercaria from L. natalensis from the Okavango Delta, Botswana and Nadasan and Appleton (2003) described a pharyngeal longifurcate distome cercaria shed by B. tropicus from Durban, KwaZulu-Natal. The present study adds to the descriptions of strigeid cercariae by the abovementioned authors from various regions in Africa.

With its unique grouping of penetration glands, strigea cercaria A is closely related to the strigea cercaria described by Fain (1953) but has penetration glands that are located at the post-acetabular region, whereas the one previously described has penetration glands situated at the preacetabular region. Other differences were size and shape of the body, as well as the flame cell formula.

With its cluster penetration glands, strigea cercaria B is similar to the strigea cercaria described by King and Van As (2001) secreted by B. tropicus in the Free State Province. The present cercaria is, however, smaller and has fewer penetration glands and flame cells. Strigea cercaria B has seven pairs of flame cells, three pairs anteriorly and four pairs posteriorly to the acetabulum; whereas, the one described by King and Van As (2001) has two pairs anteriorly and two pairs posterior to the acetabulum. Although the internal morphology of these two cercariae is similar, SEM revealed external differences; for example, the surface spines and features of the acetabulum. The cercariae described by Porter (1938) and Jansen van Rensburg (2001) were all shed by $L$. natalensis. All of the abovementioned cercariae differ from the description of the present cercaria based on the position and shape of the penetration glands, body size and caudal bodies in the tail. Interestingly, strigea cercaria B was collected only once from L. natalensis from Boekenhoutskloof farm Dam. It is too soon to comment whether or not this was an accidental infection or whether the parasite is adapting to a new first intermediate host.

With regard to the position and size of the penetration glands, strigea cercaria $C$ is clearly different in most morphological aspects to that described by King and Van As (2001) and Jansen van Rensburg (2001). This cercaria, however, resembles most of the characteristic features of C. scheerpoortia, as described by Porter (1938), especially the three pairs of penetration glands on each side of the body posterior to the acetabulum. Strigea cercaria $C$ has three pairs of flame cells anteriorly and three pairs posteriorly, unlike C. scheerpoortia, which has three pairs of flame cells occurring anteriorly, two pairs occurring posteriorly and one pair occurring in the tail stem. The cercaria described here also has hair-like structures found on either side of the body and the tail, which differs from the strigea cercaria described by Porter (1938). Other differences are the size of the intestinal caeca, tail stem morphology and pharynx size and shape.

Four types of metacercariae were obtained from local freshwater fish from the same localities. Two types of strigea metacercariae were found to encyst in the muscle tissue of Tilapia sparrmanii, Smith 1840 and Pseudocrenilabrus philander, Weber 1897, one was found in the cranial cavity of Clarias gariepinus, Burchell 1822 and a fourth in the vitreous chamber of T. sparrmanii.

According to Olsen (1974) members of the superfamily Strigeoidea belong to the families Diplostomatidae and Strigeidae, which both include intestinal parasites of fisheating and frog-eating birds and mammals. Gibson, Jones and Bray (2001) mentioned that members of the Strigeidae are mainly specific to birds but are also found in reptiles. Only one genus, Duboisiella Baer, 1938 occurs in mammals. The lifecycles of these strigea cercariae are presently still unknown, but they may develop into adults in either of the families mentioned above. With these parasites infecting a wide spectrum of freshwater fish, it is important to gather much more information on their larval stages first in order to attempt lifecycle studies in the future.

\section{Conclusion}

In this study, L. natalensis was found to host two different strigea cercariae. The first is characterised by two penetration glands flanking each other, followed by two unpaired penetration glands lying tandem and posterior to the first pair. The second cercaria is characterised by three pairs of granular penetration glands found in tandem posterior to the acetabulum. Bulinus tropicus secreted one strigea cercaria characterised by two non-pigmented eyespots and a cluster of four penetration glands situated at the terminal end of each intestinal caecum.

The three Strigea cercariae described in the present study were unrelated to any previous investigations described in the text. This investigation thus adds important findings with regard to morphological characterisation of these parasites. Our prelimenary studies have shown that many freshwater fish species are infected with various strigea metacercariae which were collected from the same waterbodies that are presently utilised by the neighbouring communities. It is therefore imperative to trace the origin of these cysts in local fish species that may serve as the main source of protein.

\section{Acknowledgements}

Scanning electron microscopy equipment utilised during this investigation was supported by the Department of Science and Technology in partnership with the National Research Foundation of South Africa. 


\section{Competing interests}

The authors declare that they have no financial or personal relationship(s) which may have inappropriately influenced them in writing this paper.

\section{Authors' contributions}

E.B.E.M. (University of Limpopo) was the principal investigator, as this study formed part of her doctoral thesis. P.H.K. (University of Limpopo) was the postgraduate supervisor of this study and C.B. (University of Limpopo) was a co-worker involved with all aspects of micrography and technical finishing of photographic plates.

\section{References}

Combes, C., 1980, 'Atlas mondial des cercaires [World atlas of the cercariae]', Mémoires du Muséum National d'Histoire Naturelle, Paris 115, 1-236.

Fain, A., 1953, Contribution à l'étude des formes larvaires des trematodes au Congo Belge et spécialment de la larvae de Schistosoma mansoni [Contribution to the study of the larval forms of the trematodes in Belgian Congo and especially of the larvae of Schistosoma mansoni]. Mémoires Institut Royal Colonial Belge Section de Sciences Naturalles et Médicales 22, 1-312.
Frandsen, F. \& Christensen, N.O., 1984, 'An introductory guide to the identification of cercariae from African freshwater snails with special reference to cercariae of
trematode species of medical and veterinary importance', Acta Tropica 41, 181202. PMid:6206702

Gibson, D.I., Jones, A. \& Bray, R.A., 2001, Keys to the Trematoda, vol. 1, CABI Publishing, London.

Jansen van Rensburg, C.J., 2001, 'Snail borne larval trematodes of the Okavango Delta, Botswana', MSc dissertation, Department of Zoology, University of the Free State.

King, P.H. \& Van As, J.G., 1997, 'Morphology and scanning electron microscopy of cercariae shed by Bulinus tropicus (Krauss, 1848) in the Free State, South Africa', Journal of African Zoology 111, 301-312.

King, P.H. \& Van As, J.G, 2001, 'Cercariae shed by Bulinus tropicus (Krauss, 1848) in the Free State, South Africa', Journal of African Zoology 36, 95-105.

Nadasan, D.S. \& Appleton, C.C., 2003, 'Studies on larval trematode infections in freshwater snails in Durban, South Africa. I. Morphology and surface topography of cercariae', Proceedings of a Workshop on African Freshwater Malacology, Kampala, Uganda, 133-166.

Olsen, O.W., 1974, Animal parasites - Their life cycles and ecology, 3rd edn., University Park Press, Baltimore.

Porter, A., 1938, 'The larval Trematoda found in certain South African Mollusca with special reference to Schistosomiasis (Bilharziasis)', South African Journal of Medical Research Institute VIII(XLII), 471.

Van Eeden, J.A., 1960, 'Key to the genera of South African freshwater and estuarine gastropods (Mollusca)', Annals of Transvaal Museum 24, 1-17.

Vercammen-Grandjean, P.H., 1960, Les trematodes du Lac Kivu sud. Musée Royal de I'Afrique Centrale, Tervuren [The trematodes of Lake Kivu south. Royal Museum of Central Africa, Tervuren]. Belgique Annales Novelle serie in $4^{\circ}$ Sciences Zoologiques 5, 1-171. 